\title{
Effects of lignin modification on wheat straw cell wall deconstruction by Phanerochaete chrysosporium
}

\author{
Jijiao Zeng, Deepak Singh, Difeng Gao and Shulin Chen ${ }^{*}$
}

\begin{abstract}
Background: A key focus in sustainable biofuel research is to develop cost-effective and energy-saving approaches to increase saccharification of lignocellulosic biomass. Numerous efforts have been made to identify critical issues in cellulose hydrolysis. Aerobic fungal species are an integral part of the carbon cycle, equip the hydrolytic enzyme consortium, and provide a gateway for understanding the systematic degradation of lignin, hemicelluloses, and cellulose. This study attempts to reveal the complex biological degradation process of lignocellulosic biomass by Phanerochaete chrysosporium in order to provide new knowledge for the development of energy-efficient biorefineries.
\end{abstract}

Results: In this study, we evaluated the performance of a fungal biodegradation model, Phanerochaete chrysosporium, in wheat straw through comprehensive analysis. We isolated milled straw lignin and cellulase enzyme-treated lignin from fungal-spent wheat straw to determine structural integrity and cellulase absorption isotherms. The results indicated that $P$. chrysosporium increased the total lignin content in residual biomass and also increased the cellulase adsorption kinetics in the resulting lignin. The binding strength increased from $117.4 \mathrm{~mL} / \mathrm{g}$ to $208.7 \mathrm{~mL} / \mathrm{g}$ in milled wood lignin and from $65.3 \mathrm{~mL} / \mathrm{g}$ to $102.4 \mathrm{~mL} / \mathrm{g}$ in cellulase enzyme lignin. A detailed structural dissection showed a reduction in the syringyl lignin/guaiacyl lignin ratio and the hydroxycinnamate/lignin ratio as predominant changes in fungi-spent lignin by heteronuclear single quantum coherence spectroscopy.

Conclusion: P. chrysosporium shows a preference for degradation of phenolic terminals without significantly destroying other lignin components to unzip carbohydrate polymers. This is an important step in fungal growth on wheat straw. The phenolics presumably locate at the terminal region of the lignin moiety and/or link with hemicellulose to form the lignin-carbohydrate complex. Findings may inform the development of a biomass hydrolytic enzyme combination to enhance lignocellulosic biomass hydrolysis and modify the targets in plant cell walls.

Keywords: NMR, Lignin degradation, White rot fungi, Lignin-carbohydrate complex, Cellulase absorption, Solid-state NMR, Inter-unit linkages, Milled wood lignin, Cellulase enzyme lignin

\section{Background}

Lignocellulosic biomass consists of $\beta$-(1,4)-linked glucose polymer cellulose, hemicellulose polysaccharides of varying composition, and lignin. To increase the sugar yield from biomass, pretreatment technologies primarily lead to three main physicochemical alterations: 1) cleavage of lignincarbohydrate bonds and removal of hemicellulose, 2) lignin modification and degradation, and 3) decrystallization of cellulose [1]. Two of these three relate to lignin and its

\footnotetext{
*Correspondence: chens@wsu.edu

Department of Biological Systems Engineering, Bioprocessing and

Bioproduct Engineering Laboratory (BBEL), Washington State University, L.J. Smith 213, Pullman, Washington 99163, USA
}

derivatives. Lignin fills the spaces in the cell wall between cellulose, hemicellulose, and pectin components, especially in tracheid, sclereid, and xylem cells [2]. It also links hemicellulose $[1,3]$ depositing on the cellulose surface, thus constituting an obstruction for effective hydrolysis.

Structurally, lignin is a polymer of heterogeneous phenylpropanoid units in vascular plants that is built randomly by oxidative coupling between hydroxyphenyl $(\mathrm{H})$, guaiacyl $(\mathrm{G})$, and syringyl (S), which are derived from three corresponding monolignols: $p$-coumaryl alcohol ( $p$ CoumA), coniferyl alcohol (ConA), and sinapyl alcohol (SinA). This leads to the most chemically resistant structures due to aromaticity and a diverse set of $\mathrm{C}-\mathrm{C}$ and $\mathrm{C}-\mathrm{O}$ cross-links 
[4]. Moreover, due to variations in the coupling process and the distribution of basic units in plant tissue, the structural properties are dictated by the variety of chemically distinct linkages $[5,6]$. However, their roles in the enzymatic hydrolysis of cellulose are not fully understood. Lignin has been found to spontaneously absorb cellulase $[7,8]$. The microfibrillar architecture analysis of cell walls suggests that digestion minimizes the lignin barrier and maintains the native polysaccharide architecture [9]. On the other hand, the correlation of lignin content to cellulose hydrolysis is weak in terms of functionality and composition [10]. In fact, high levels of delignification without a significant increase in cellulose accessibility do not result in the expected digestibility [11].

Biodegradation systems such as Phanerochaete chrysosporium form an enormous source of lignocellulolytic enzymatic complexes [12]. These naturally provide novel resources for the delignification of bioenergy crops and other sources of lignocellulosic biomass [13,14]. During delignification, three predominant reactions occur: 1) side chain oxidation $\left(\mathrm{C}_{\alpha}-\mathrm{C}_{\beta}\right.$ cleavage $\left.), 2\right)$ ring hydroxylation, and 3) demethylation [15]. The current model for lignin breakdown is derived from studies of fungal metalloenzymes and based on oxidative combustion of lignin through various radical-mediated paths. This process ultimately generates phenoxyl and phenyl radicals on the substrate, followed by depolymerization [16,17]. Lignin peroxidase (LiP) executes the $\mathrm{H}_{2} \mathrm{O}_{2}$-dependent $\mathrm{C}_{\alpha}-\mathrm{C}_{\beta}$ cleavage of lignin, based on the reports on LiPdependent model compound degradation, which is subsequently shown to catalyze the partial depolymerization of methylated lignin in vitro $[18,19]$. Nonphenolic syringyl and biphenyl model compounds are oxidized by LiP. In contrast, manganese peroxidase $(\mathrm{MnP})$ is not effective in countering nonphenolic lignin degradation. However, biomimetic oxidation of lignin model compounds by $\mathrm{Mn}^{3+}$ suggest that it may play a role in oxidizing both phenolic and nonphenolic residues of lignin [20] via a lipid peroxidation reaction [21] or in the presence of cellobiose dehydrogenases $(\mathrm{CDH})$ [22].

The role of lignin biodegradation during the fungal utilization of lignocellulosic biomass is still not fully understood [23,24]. In fact, there is little evidence to support the concept of lignin being used as a carbon source or nutrient to increase growth. Biodelignification is generally thought to either increase cellulose accessibility, retain cellulase activity, or both. Previous studies suggest that clarification of a detailed skeleton of plant cell walls during fungal biodegradation can enhance biomass conversion technology [23]. Great efforts have been made in investigating lignin biodegradation reactions [15]; however, the role of lignin in subsequent cellulose digestion in biological systems is still ambiguous.
This study attempts to evaluate the key steps of lignin biodegradation on wheat straw and it explores new biological strategies for lignin degradation and its potential for biomass hydrolysis technology. The findings provide detailed structural data on lignin from fungalspent wheat straw through comprehensive NMR analysis. This study also explores the adsorption isotherms of cellulases for lignin in order to evaluate the influence of lignin adsorption capacity on cellulose hydrolysis.

\section{Results and discussion}

The growth of $P$. chrysosporium on wheat straw led to a significant weight reduction in biomass, which was dependent on the treatment time (Figure 1A). After eight weeks of fungal treatment, the wheat straw mass decreased dramatically to $32.86 \pm 4.04 \mathrm{~g}$ from $100 \mathrm{~g}$ original dry weight (about $70 \%$ less than the initial weight of the biomass). The first two weeks of treatment involved the most dramatic weight loss of biomass at about $20 \%$ (Additional file 1: Table S1). Compositional analysis revealed the simultaneous degradation of lignin and carbohydrates. However, the relative reduction of carbohydrate/ lignin $(\mathrm{C} / \mathrm{L})$ ratio was also recorded in the treated samples. The $\mathrm{C} / \mathrm{L}$ ratio decreased from 4.0 to 2.4 within eight weeks of incubation time (Figure 1B), indicating a substantial utilization of carbohydrates compared to lignin. This diminished $\mathrm{C} / \mathrm{L}$ ratio was confirmed by solid-state ${ }^{13} \mathrm{C}$ NMR analysis.

The peak area from 93 to $82 \mathrm{ppm}$ was assigned to crystalline and amorphous signals for $\mathrm{C} 4$ of the cellulose polymer [25] (Figure 1B). Crystallinity estimates for the biomass (CrI) ranged from 32.1 to $17.7 \%$ for two to eight weeks of incubation (Figure 1B). The increased efficiency of enzymatic hydrolysis of the fungal-spent straw is in accordance with the reduced crystallinity. The total sugar release was three to four times higher in the wheat straw treated for eight weeks compared to the control (Figure 1C). The cellobiose oxidase and cellobiose quinone oxidoreductase derived from $P$. chrysosporium were found to strongly bind with crystalline region of cellulose $[26,27]$, enhancing the crystalline cellulose degradation by cellulases [27]. But due to the blurred boundary between the crystalline and amorphous regions (Figure 1B), the CrI of the eight-week sample might be underestimated.

$P$. chrysosporium has a strong ability to produce hydrolytic enzymes that dissociate numerous interlocks in biomass substructures. These include various glycoside hydrolase $(\mathrm{GH})$ family proteins, such as cellobiohydrolase (EC 3.2.1.4), endoglucanase (EC 3.2.1.4), cellobiose dehydrogenase (EC 1.1.99.18), $\beta$-glucosidase (EC 3.2.1.21), xylanase (EC 3.2.1.8), polygalacturonase (EC 3.2.1.15), xylan esterase (EC 3.2.1.72), arabinase (EC 3.2.1.99), and mannanases (EC 3.2.1.78), as well as lignin degradation enzymes, including lignin peroxidase (LiP) (EC 1.11.1.14), 


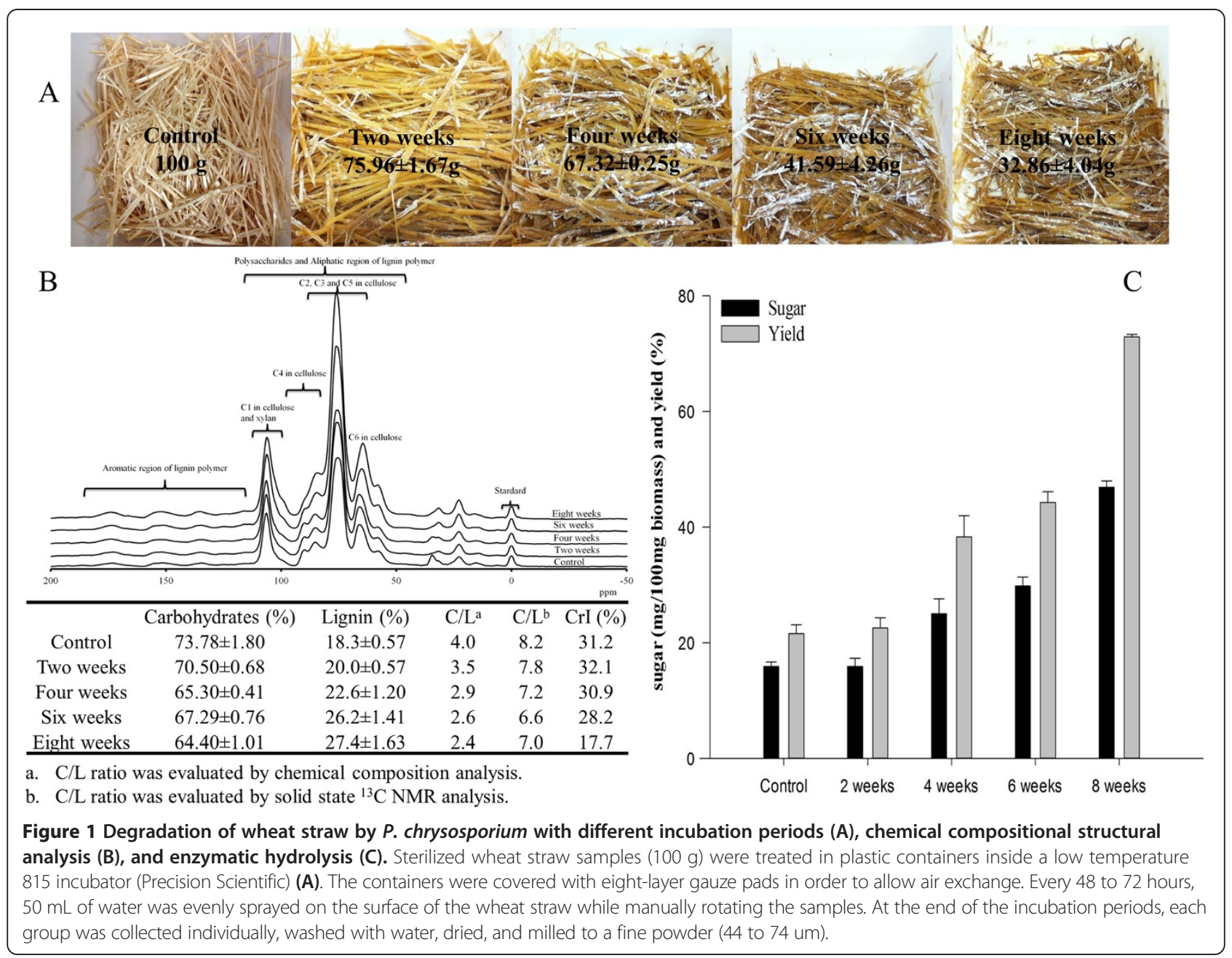

manganese peroxidase (MnP) (EC 1.11.1.13), copper radical oxidases (EC 3.2.1.4), glyoxal oxidase (E.C 1.1.3.-), and quinone oxidoreductase (EC 1.6.99.21) [12,24,28,29]. During biological degradation of the wheat straw, our findings show that over $50 \%$ of the carbohydrate and lignin was digested within eight weeks (Additional file 1: Table S1). However, the changes in $\mathrm{C} / \mathrm{L}$ ratios (Figure 1B) suggest that lignin degradation gradually slowed down compared to consumption of total cellulose and hemicellulose. In contrast, high lignin content did not affect the saccharification efficiency (Figure 1C).

Studies show that cellulose accessibility $[11,30]$ and lignin composition/characteristics [10] strongly influence enzymatic hydrolysis. Elevated enzymatic hydrolysis for the fungal-spent biomass can be partially explained by a decrease in CrI (Figure 1B). However, it is possible that biologically degraded lignin may lower absorption effects on cellulase and/or inhibition to cellulases because the active functional groups are saturated or otherwise unavailable during fungal growth in biomass.
To test this hypothesis, we isolated milled straw lignin (MSL) and cellulase enzyme lignin (CEL) and used them to represent the possible influence of chemical properties on cellulase adsorption. As shown in Figure 2, the adsorption data followed the Langmuir isotherm well $\left(R^{2}>0.95\right)$, estimated with nonlinear regression using Polymath. This verified that biologically modified wheat straw lignin absorbs more cellulase than native lignin. MSL showed higher maximum adsorption abilities than CEL (Table 1). Treated samples of both types of lignin had higher maximum adsorption capacities than untreated lignin, as well as higher affinity. The range of adsorption parameters (maximum adsorption capacity and affinity) agreed with previous studies that used chemical pretreatments, such as ammonia fiber expansion (AFEX), dilute acid, organosolv, and $\mathrm{SO}_{2}$-steam $[7,31,32]$ (Table 1). MSL showed a higher maximum adsorption capacity than CEL, presumably because MSL contains lower amounts of carbohydrate residues. This results in higher exposure of lignin units to cellulase (Additional file 2: Table S2). However, 

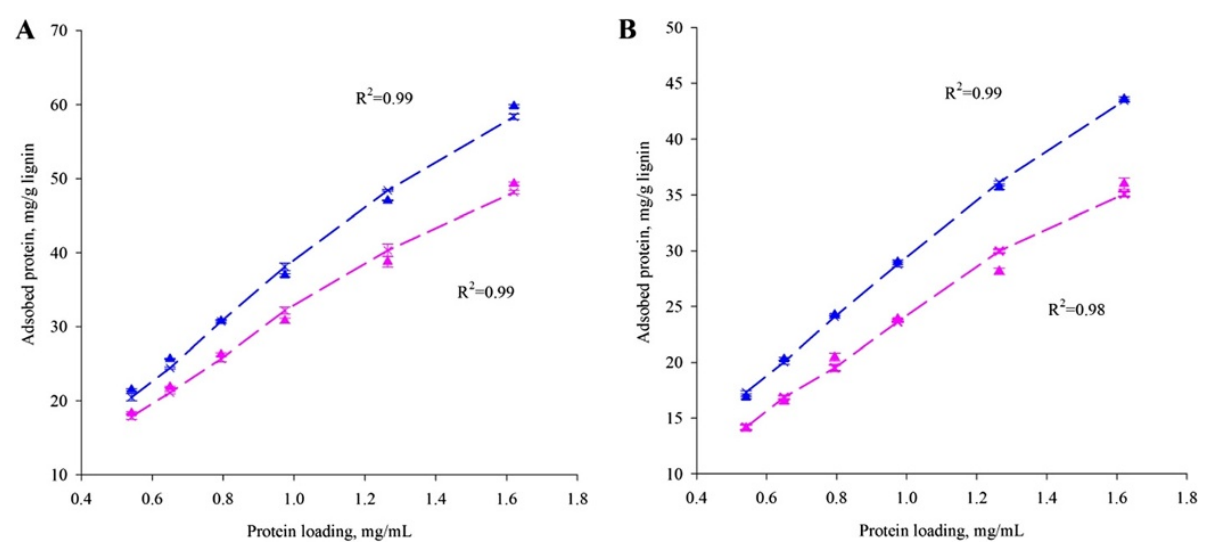

Figure 2 Cellulase adsorption on MSL (A) and CEL (B) at $4^{\circ} \mathrm{C}$. Adsorbed cellulase on control lignin (pink) and eight weeks treated lignin (blue) was determined by subtraction of protein in supernatant from total loaded protein. Experimental data (triangles), data predicted by Langmuir equation (crosses with dashed lines). Error bars represent standard deviation.

against our expectations, lignin that is biologically degraded and/or modified by $P$. chrysosporium could capture more cellulase in both MSL and CEL.

Hydrophobicity (lignin part) or hydrophilicity (carbohydrate part) of lignin-carbohydrate complexes (LCCs) may produce nonproductive (retarding saccharification) as well as productive (facilitating saccharification) binding of enzymes, respectively [32]. Hydrophobic interaction is considered to be the major interaction between lignin and cellulases $[31,33,34,35]$. It is also possible that some GH homologs with a cellulose-binding domain (CBD) may bind to the surface of the MSL/CEL's LCC, causing a higher cellulase adsorption ability. The CBDs of families I, II, and III have a carbohydrate-binding cleft where a set of aromatic residues and a group of polar residues occur [36]. However, cellulose hydrolysis results showed a higher sugar yield for modified lignin (Figure 2 and Table 1) when cellulases are added in wheat straw saccharification (Figure 1). Therefore, this effect cannot be explained by reducing the unproductive binding of cellulases to lignin.
To explore the potential role of lignin degradation on saccharification, we performed a structural analysis of lignin with heteronuclear single quantum coherence spectroscopy (HSQC) NMR. The spectra were compared for untreated milled straw lignin (MSL) and cellulase enzyme lignin (CEL), with major structures in aromatic $\left(\delta_{\mathrm{C}} / \delta_{\mathrm{H}} 160-102 / 8.0-6.0 \mathrm{ppm}\right)$ and aliphatic regions $\left(\delta_{\mathrm{C}} / \delta_{\mathrm{H}} 90-50 / 6-3 \mathrm{ppm}\right)$. The major structures and interunit linkages are listed in Figure 3. Previous studies detail the chemical shifts and assignments of various lignin moieties from wheat straw [36]. In the aromatic regions of HSQC spectra, tricin (T), guaiacyl lignin (G), syringyl lignin $(\mathrm{S}), p$-coumarate $(p \mathrm{CA})$, and ferulate (FA) were found to form the backbone of wheat straw lignin (Figure 4). Differences were mainly observed in terms of signal reduction corresponding to $\alpha / \beta$ correlations from ferulate and $p C A$, as well as cinnamyl alcohol (X1) and cinnamyl aldehyde (X2). This suggests a queue of lignin degradation patterns by this fungus on wheat straw. The aliphatic regions of HSQC spectra of MSL and CEL show comparable signals from arylglycerol- $\beta$-aryl ether $(\beta-\mathrm{O}-4)$, pino/resinol

Table 1 Parameters of cellulase adsorption on MSL and CEL isolated from biological treated and untreated wheat straw

\begin{tabular}{llllllll}
\hline Lignin isolation & ${ }^{\circ} \mathbf{C}$ & Biomass & Pretreatment & $\boldsymbol{\sigma}(\mathbf{m g} / \mathbf{g}$ lignin) & $\mathbf{A}(\mathbf{L} / \mathbf{g})$ & $\mathbf{S}=\mathbf{\sigma} \times \mathbf{A}(\mathbf{m L} \mathbf{g})$ & Reference \\
\hline EnzL & 4 & Poplar & AFEX & 56.8 & 2.14 & 121.6 & Kumar, R and C.E. Wyman, 2009 [7] \\
EnzL & 4 & Corn stover & DA & 53 & 0.68 & 36.0 & Kumar, R and C.E. Wyman 2009 [7] \\
CEL & 50 & Douglas fir & SO $_{2}$-steam & 79.3 & 1.86 & 147.5 & Nakagame, S., et al., 2011a [31] \\
CEL & 50 & Lodgepole pine & Organosolv & 34.9 & 1.43 & 49.9 & Nakagame, S., et al., 2011b [32] \\
MSL & 4 & Wheat straw & Untreated & 136.2 & 0.86 & 117.4 & In this study \\
MSL & 4 & Wheat straw & P. chrysosporium & 171.1 & 1.22 & 208.7 & In this study \\
CEL & 4 & Wheat straw & Untreated & 86.9 & 0.75 & 65.3 & In this study \\
CEL & 4 & Wheat straw & P. chrysosporium & 100.4 & 1.02 & 102.4 & In this study
\end{tabular}

The adsorption capacity ( $\sigma$ ), affinity constant (A), and strength of binding (S) were evaluated by fitting Langmuir isotherm model. EnzL: enzyme lignin; AFEX: ammonia fiber expansion; DA: dilute acid. 


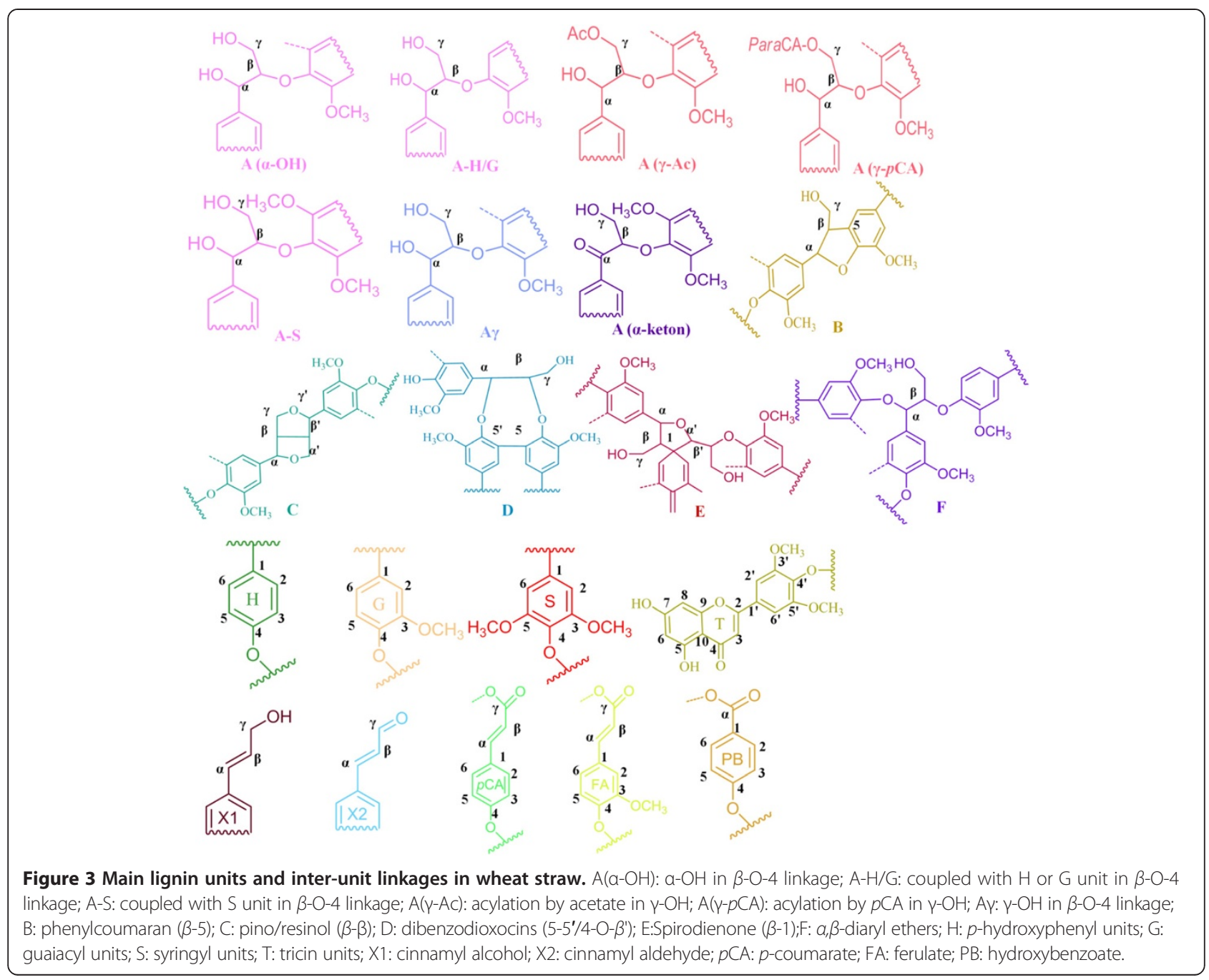

$(\beta-\beta)$, and dibenzodioxocin $\left(5-5^{\prime} / 4-O-\beta^{\prime}\right)$ linkages. However, weaker correlations of $\gamma$-ending groups, $\gamma$-acylation groups, phenylcoumaran $(\beta-5)$, and $\alpha, \beta$-diaryl ether $(\alpha-\mathrm{O}$ $4 / \beta$-O-4) were detected (Figure 5 ). Polysaccharide signals were also intensified in CEL, possibly due to exposure of LCCs by additional cellulase treatment of the lignin residues, which exhibited more $\beta$-D-xylan and arabinose [38].

Quantification of the lignin units and inter-unit linkages from isolated MSL and CEL are summarized in Table 2. Interestingly, $P$. chrysosporium led to relatively low values in S/G ratios, with increased $T$ units from 8.5 to 12 units in MSL, and from 5.6 to 7.3 units in CEL, respectively. The lower S/G ratios in fungal biodegradation resulted in a greater cellulose accessibility. Higher S/G ratios in the deposited lignin during the hydrothermal pretreatment are reported to inhibit cellulose hydrolysis [39]. Moreover, reduction of hydroxybenzoate (PB), $p C A$, and FA units subsequently lower cinnamate/lignin ratios. The $\beta-\mathrm{O}-4, \beta-5$, and $\beta-\beta^{\prime}$ inter-unit linkages of biologically treated and untreated lignin occupy over
90\% of side chains with the exception of the D and $\mathrm{F}$ units in the aliphatic region. A comparison of isolated MSL and CEL further reveals that $P$. chrysosporium degrades the B and F units compared to the A, C, and D units. Special attention was paid to $\gamma$-ending groups, as they strongly relate with hydroxycinnamates. Consistent with results for the aromatic region (Figure 4 and Table 2), $\gamma-\mathrm{OH}$ in the $\mathrm{X} 1$ structure decreased from 2.0 to 1.2 units in MSL, and from 1.5 to 0.9 units in CEL. $\gamma$ acylation decreased from 5.4 to 2.0 units in MSL, and from 15.6 to 9.8 units in CEL. We further analyzed CEL lignin that was isolated from wheat straw treated for two, four, and six weeks with quantitative NMR (Additional file 3: Figure S1 and Additional file 4: Figure S2). Quantitative analysis revealed similar trends for the modification of lignin (Table 3).

Clearly, the relative decrease in $\mathrm{S}$ units along with the relative increase in $\mathrm{G}$ units caused an overall decrease in $\mathrm{S} / \mathrm{G}$ ratios. Two key points explain the "fragility" of the $\mathrm{S}$ unit [40] over the $G$ unit: i) $S$ units have less redox 


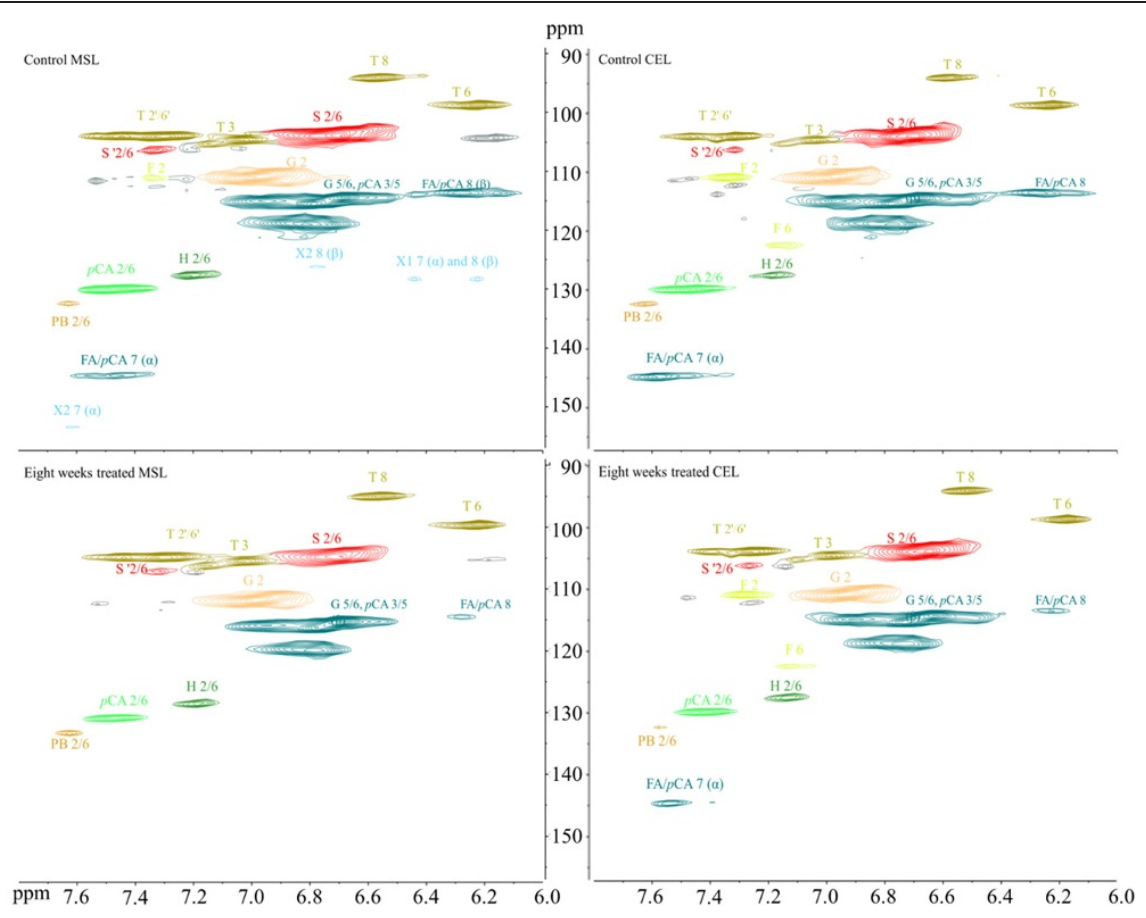

Figure 4 The aromatic region of MSL and CEL isolated from eight weeks, treated and untreated, wheat straw in HSQC spectra.

H: $p$-hydroxyphenyl units; G: guaiacyl units; S: syringyl units; T: tricin units; X1: cinnamyl alcohol; X2: cinnamyl aldehyde; $p$ CA: $p$-coumarate; FA: ferulate; PB: hydroxybenzoate.

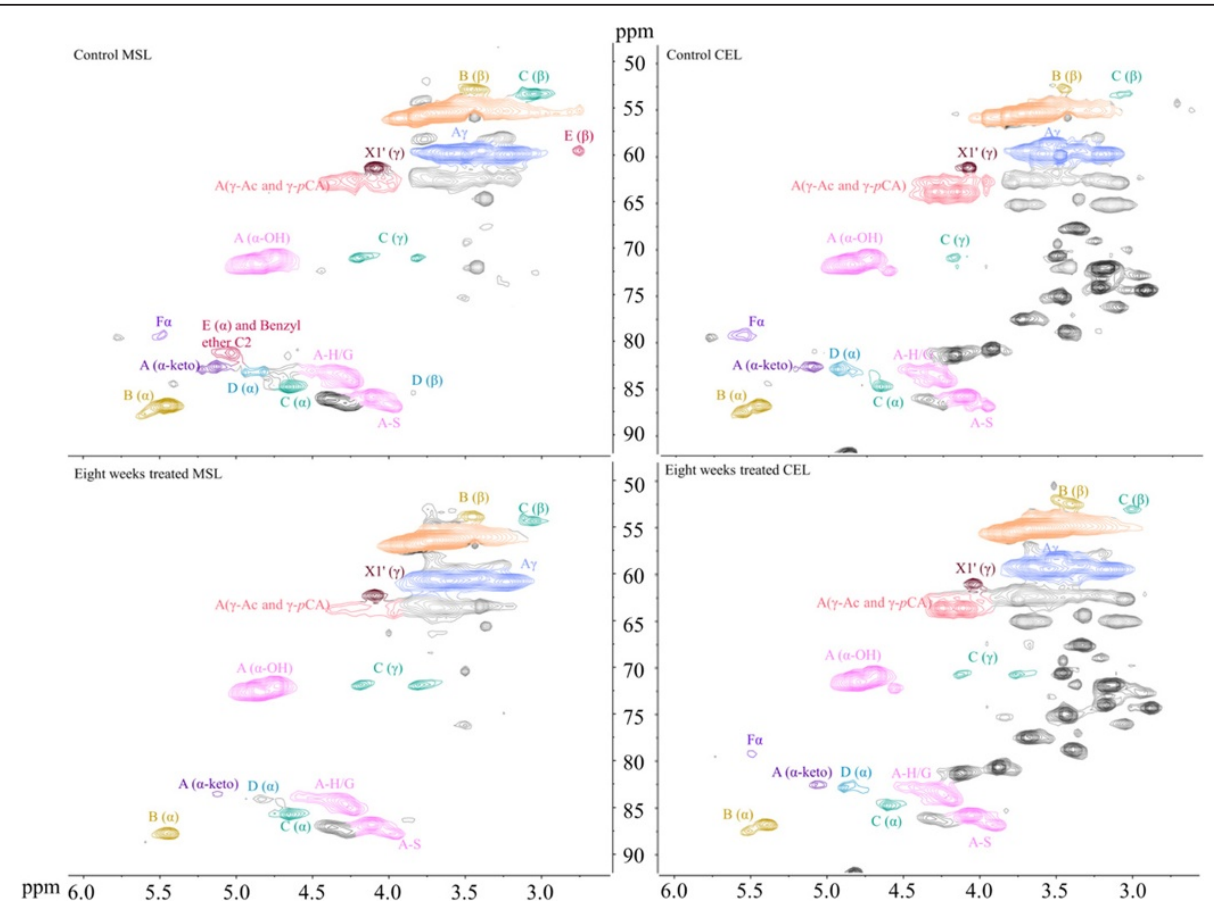

Figure 5 The aliphatic region of MSL and CEL isolated from eight weeks, treated and untreated, wheat straw in HSQC spectra. A( $(\mathrm{A}-\mathrm{OH})$ : $\mathrm{a}-\mathrm{OH}$ in $\beta$-O-4 linkage; $\mathrm{A}-\mathrm{H} / \mathrm{G}$ : coupled with $\mathrm{H}$ or $\mathrm{G}$ unit in $\beta-\mathrm{O}-4$ linkage; A-S: coupled with $\mathrm{S}$ unit in $\beta-\mathrm{O}-4$ linkage; $\mathrm{A}(\gamma-\mathrm{Ac})$ : acylation by acetate in $\gamma-\mathrm{OH}$; $\mathrm{A}(\gamma-p C A)$ : acylation by $p C A$ in $\gamma-\mathrm{OH}$; $\mathrm{A} \gamma$ : $\gamma-\mathrm{OH}$ in $\beta-\mathrm{O}-4$ linkage; $\mathrm{B}$ : phenylcoumaran ( $\beta-5)$; $\mathrm{C}$ : pino/resinol $(\beta-\beta)$; D: dibenzodioxocins $\left(5-5^{\prime} / 4-\mathrm{O}-\beta^{\prime}\right)$; F: $\alpha, \beta$-diaryl ethers. 
Table 2 Quantification of aromatic moieties (lignin, hydroxycinnamates, inter-unit bondages) by combination analysis of ${ }^{13} \mathrm{C}$ and HSQC NMR spectra of wheat straw isolated MSL and CEL

\begin{tabular}{|c|c|c|c|c|c|}
\hline Aromatic moieties & $\sigma_{\mathrm{C}} / \sigma_{\mathrm{H}}(\mathrm{ppm})$ and assignments & Control MSL & Control CEL & Eight weeks MSL & Eight weeks CEL \\
\hline \multicolumn{6}{|l|}{ Lignin aromatic units } \\
\hline \multirow[t]{2}{*}{ Syringyl (S) } & 103.9/6.7 (S2/6), & 25.7 & 27.3 & 24.1 & 24.5 \\
\hline & 106.4/7.4 (S'2/6 with a oxidization) & & & & \\
\hline \multirow[t]{2}{*}{ Guaiacyl (G) } & $110.8 / 6.97(G 2)$ & 41.2 & 39.3 & 41.6 & 39.8 \\
\hline & 115.0/6.94 (G5),118.9/6.81 (G6) & & & & \\
\hline p-hydroxyphenyl $(\mathrm{H})$ & $127.7 / 7.21(\mathrm{H} 2 / 6)$ & 1.6 & 1.4 & 2.3 & 1.8 \\
\hline S/G ratio & & 0.63 & 0.69 & 0.58 & 0.61 \\
\hline \multicolumn{6}{|l|}{ Hydroxycinnamates } \\
\hline p-benzoate (PB) & 132.4/7.63 (PB2/6) & 0.5 & 1.2 & 1.3 & 0.2 \\
\hline \multirow[t]{2}{*}{$p$-coumarate $(p C A)$} & 130.0/7.47 (pCA2/6), 115.5/6.79 (pCA3/5) & 5.4 & 5.5 & 3.0 & 3.1 \\
\hline & $144.74 / 7.47$ & & & & \\
\hline Ferulate (FA) & 110.9/7.32 (FA2), 122.5/7.15 (FA6) & 0.6 & 6.4 & 0.4 & 4.5 \\
\hline$p$-coumarate/ferulate & & 9 & 0.86 & 7 & 0.68 \\
\hline Cinnamates/lignin and tricin & & 0.09 & 0.18 & 0.06 & 0.11 \\
\hline \multicolumn{6}{|l|}{ Lignin-ending group } \\
\hline Cinnamyl aldehyde (X2) & 153.5/7.62 (X2a), 126.2/6.78 (X2ß) & 0.1 & ND & ND & ND \\
\hline Cinnamyl alcohol (X1) & $128.34 / 6.44(X 1 a), 128.35 / 6.22(X 1 \beta)$ & 0.6 & ND & ND & ND \\
\hline \multicolumn{6}{|l|}{ Lignan } \\
\hline \multirow[t]{2}{*}{ Tricin $(T)$} & $104.04 / 7.30$ (Т 2'/6'), 104.65/7.03 (Т3) & 8.5 & 5.6 & 12 & 6.6 \\
\hline & 94.1/6.56 (T8), 98.8/6.22 (T6) & & & & \\
\hline \multicolumn{6}{|l|}{ Inter-unit bondages } \\
\hline $\mathrm{a}-\mathrm{OH} / \beta-\mathrm{O}-4$ & 71.1/4.74 (Aa-G), 71.8/4.8 (Aa-S) & 28.3 & 33.8 & 31.7 & 36.5 \\
\hline a-keto/ß-O-4 & 82.7/5.1 (Aa-keto) & 1.5 & 2.4 & 0.4 & 1.1 \\
\hline Total $\beta-\mathrm{O}-4$ & & 29.8 & 36.2 & 32.1 & 37.6 \\
\hline Phenylcoumaran $(\beta-5)$ & 85.9/5.5 (Ba), 53.0/3.4 (Bß) & 5.4 & 5.7 & 3.0 & 4.1 \\
\hline Pino/resinol $(\beta-\beta)$ & 84.8/4.7 (Ca), 53.5/3.1 (Cß), & 1.3 & 0.9 & 1.4 & 1.2 \\
\hline Dibenzodioxocin (D) & 83.4/4.9 (Da), 85.5/3.8 (Dß) & 0.3 & 2.0 & 0.7 & 2.5 \\
\hline Spirodienone (SD) & 81.4/5.0 (SDa), 59.5/2.8 (SDß) & 0.4 & ND & ND & ND \\
\hline a, $\beta$-diaryl ether ( $F$ ) & 79.6/5.5 (Fa) & 0.5 & 2.1 & 0.4 & 1.3 \\
\hline \multicolumn{6}{|l|}{$\gamma$-ending groups } \\
\hline $\mathrm{Y}-\mathrm{OH}$ in $\mathrm{X} 1$ structure & $62-58 / 3.8-3.0$ & 2.0 & 1.5 & 1.2 & 0.9 \\
\hline Acylation on $\gamma$ position & $60.8-58.8 / 3.8-3.35$ & 5.4 & 15.6 & 2.0 & 10.1 \\
\hline
\end{tabular}

potential (are more easily oxidized) than $\mathrm{G}$ and $\mathrm{H}$ units; and ii), due to the non-availability at the 5 position (taken by the methoxy group), $\mathrm{S}$ units can easily form linear structures by $\beta-\mathrm{O}-4$ [41] rather than $\beta-5$ and 5-5 structures. In addition, the spatial distribution of the syringyl unit was determined by Zhou et al. (2011) [42], who found that it showed a preferential localization in the fiber cell wall and secondary cell wall of a plant cell. Polysaccharides are also deposited in the secondary cell wall [43]. It is possible that fungi "choosing" to degrade the $S$ units may be ascribed to real-life needs: 1) $S$ units are relatively delicate; (2) removing $\mathrm{S}$ units may increase the accessibility of cellulose to cellulases.

Changes in the S/G ratio also contribute to fluctuation in $\mathrm{T}$ units. The incorporation of tricin units into herbaceous lignin [44] provides new insight into understanding the structural integrity of lignin. Our findings show that the lignin content of wheat straw strongly relies on the $\mathrm{S} / \mathrm{G}$ ratio, at up to 8 units per $100 \mathrm{Ar}$ [37]. Tricin is involved in linking to $\mathrm{G}$ units via $\beta-\mathrm{O}-4$ [44], which can misdirect the $S / G$ ratio by other analytical approaches and lead to overestimation of $\mathrm{S}$ units content at the end 
Table 3 Quantification of aromatic moieties (lignin, hydroxycinnamates, inter-unit bondages) by combination analysis of ${ }^{13} \mathrm{C}$ and HSQC NMR spectra of wheat straw isolated CEL

\begin{tabular}{|c|c|c|c|c|c|c|}
\hline Aromatic moieties & $\sigma_{\mathrm{C}} / \sigma_{\mathrm{H}}(\mathrm{ppm})$ and assignments & $\begin{array}{l}\text { Control } \\
\text { CEL }\end{array}$ & Two weeks CEL & Four weeks CEL & Six weeks CEL & $\begin{array}{l}\text { Eight } \\
\text { weeks CEL } \\
\end{array}$ \\
\hline \multicolumn{7}{|l|}{ Lignin aromatic units } \\
\hline \multirow[t]{2}{*}{ Syringyl (S) } & 103.9/6.7 (S2/6), & 27.3 & 20.5 & 19.4 & 21.3 & 24.5 \\
\hline & 106.4/7.4 (S'2/6 with a oxidization) & & & & & \\
\hline \multirow[t]{2}{*}{ Guaiacyl (G) } & 110.8/6.97 (G2) & 39.3 & 40.8 & 37.2 & 40.9 & 39.8 \\
\hline & 115.0/6.94 (G5),118.9/6.81 (G6) & & & & & \\
\hline p-hydroxyphenyl $(\mathrm{H})$ & $127.7 / 7.21(\mathrm{H} 2 / 6)$ & 1.4 & 2.2 & 2.4 & 2.3 & 1.8 \\
\hline S/G ratio & & 0.69 & 0.50 & 0.52 & 0.52 & 0.61 \\
\hline \multicolumn{7}{|l|}{ Hydroxycinnamates } \\
\hline p-benzonate (PB) & 132.4/7.63 (PB2/6) & 1.2 & ND & ND & ND & 0.2 \\
\hline$p$-coumarate $(p C A)$ & 130.0/7.47 (pCA2/6), 115.5/6.79 (pCA3/5) & 5.5 & 2.5 & 2.7 & 3.3 & 3.1 \\
\hline Ferulate (FA) & 110.9/7.32 (FA2), 122.5/7.15 (FA6) & 6.4 & 3.9 & 4.6 & 5.4 & 4.5 \\
\hline$p$-coumarate/ferulate & & 0.86 & 0.65 & 0.58 & 0.60 & 0.68 \\
\hline Cinnamates/lignin and tricin & & 0.18 & 0.09 & 0.10 & 0.12 & 0.11 \\
\hline \multicolumn{7}{|l|}{ Lignan } \\
\hline \multirow[t]{2}{*}{ Tricin (T) } & 104.04/7.30 (Т 2'/6'), 104.65/7.03 (Т3) & 5.6 & 10 & 12 & 9.0 & 6.6 \\
\hline & 94.1/6.56 (T8), 98.8/6.22 (Т6) & & & & & \\
\hline \multicolumn{7}{|l|}{ Inter-unit bondages } \\
\hline $\mathrm{a}-\mathrm{OH} / \beta-\mathrm{O}-4$ & 71.1/4.74 (Aa-G), 71.8/4.8 (Aa-S) & 33.8 & 33.9 & 28.1 & 33.9 & 36.5 \\
\hline a-keto/ß-O-4 & 82.7/5.1 (Aa-keto) & 2.4 & 0.8 & 0.6 & 0.8 & 1.1 \\
\hline Total $\beta-\mathrm{O}-4$ & & 36.5 & 34.7 & 28.7 & 34.7 & 37.6 \\
\hline Phenylcoumaran $(\beta-5)$ & 85.9/5.5 (Ba), 53.0/3.4 (Bß) & 5.7 & 4.2 & 3.3 & 5.2 & 4.2 \\
\hline Pino/resinol $(\beta-\beta)$ & 84.8/4.7 (Ca), 53.5/3.1 (Cß), & 0.9 & 1.2 & 1.6 & 1.5 & 1.2 \\
\hline Dibenzodioxocin (D) & 83.4/4.9 (Da), 85.5/3.8 (Dß) & 2.0 & 3.8 & 2.7 & 4.0 & 2.5 \\
\hline Spirodienone (SD) & 81.4/5.0 (SDa), 59.5/2.8 (SDß) & ND & ND & ND & ND & ND \\
\hline a, $\beta$-diaryl ether (F) & 79.6/5.5 (Fa) & 2.1 & ND & ND & ND & 1.3 \\
\hline \multicolumn{7}{|l|}{ y-ending groups } \\
\hline $\mathrm{Y}-\mathrm{OH}$ in $\mathrm{X} 1$ structure & $62-58 / 3.8-3.0$ & 1.5 & 0.9 & 0.8 & 1.0 & 0.9 \\
\hline Acylation on $\gamma$ position & $60.8-58.8 / 3.8-3.35$ & 15.6 & 11.1 & 13.1 & 11.8 & 10.1 \\
\hline
\end{tabular}

[23,45]. Gradually increasing the tricin content (Table 1 and Table 2) in P. chrysosporium-spent wheat straw suggested that tricin was not primarily involved in the biodegradation of lignin.

The decrease of hydroxycinnamates (FA, PB, and $p$ CA) (Table 2 and Table 3 ) is a typical fingerprint in biologically treated wheat straw, which contributes to free phenolic $\mathrm{OH}$ and carboxylic/carbonyl groups in herbaceous lignin. Improvement of lignocellulosic digestibility by white rot fungi is consistent with degradation of $p$ CA and FA [46]. FA is primarily esterified to arabinosyl residues of arabinoxylan chains, and feruloylated arabinoxylans are later cross-linked to $G$ units of lignins via ether bonds. Since FA is involved in ester linkages and phenol coupling reactions, it can covalently attach polysaccharide with lignin. The resultant product is a ferulate-polysaccharide-lignin complex that is bonded through ester-ether linkages [47]. Thus, FA deposition may not only lead to cell wall cross-linking during plant growth and development, but may also regulate the non-random pattern of lignin formation within the wall [48].

The elimination of $\mathrm{FA} / p \mathrm{CA} \alpha / \beta$ ' correlations (Figure 4 and Additional file 3: Figure S1) and the decrease of FA (Table 2 and Table 3) and arabinose content (Additional file 1: Table S1) confirm the cleavage of the labile ester side chain of ferulate during biodegradation. Studies show that $\gamma-\mathrm{OH}$ in wheat straw lignin is widely acylated by $p C A$ and acetate [43], while $p C A$ also can couple with the $\alpha$ position of lignin by ether linkage [49]. S units are enzymatically pre-acylated with $p$ CA [4] before incorporation into the lignin complex via $\beta-5$ or $\beta-\beta^{\prime}$ 
rather than $\beta$-ether in wheat straw [43]. The deconstruction of $\beta-5$ and $\alpha, \beta$ ether linkages (Figure 5, Table 2 and Table 3) suggests the potential incorporation pathway between hydroxycinnamate and lignin units in wheat straw. In addition, the degradation of hydroxycinnamates is possibly ascribed to the ligninase system of $P$. chrysosporium. The $p \mathrm{CA}$ is mostly presented as a free phenolic compound in the entire lignin complex, favored by $\mathrm{MnP}$ through $\alpha-\beta$ cleavage reactions (white rot fungi degradation style) $[13,15,50]$. The primary targets of hydroxycinnamates by $P$. chrysosporium during biodegradation of wheat straw lignin offer new opportunities in lignin biosynthesis to improve the biomass saccharification process.

Recent studies reveal the adverse effect of phenolics on cellulase activity [51]. Improved digestibility of biomass may also be due to the breakdown of the lignincarbohydrate complex (LCC) [4]. LCCs have been compared to the hemicelluloses, which may protect the cell wall from enzyme attack, assuming the low LCCs during biological pretreatment. This facilitates the accessibility of cellulose due to inherently bigger pores that the enzymes can penetrate (about 4 to 13 $\mathrm{nm})$. Arabinoxylan acylated FA plays a very important role in bridging lignin and hemicellulose to form LCCs $[48,52,53]$, and this has been shown to greatly affect the digestibility of lignocellulosic biomass [54,55].

However, there is still a question of how ligninases secreted by $P$. chrysosporium can selectively access these regions, since the compact structure of the cell wall rigidly prevents enzyme accessibility. Our previous proteome analysis of $P$. chrysosporium-spent wheat straw indicates the early secretion of lipases, oxidases, and esterases along with LiP that may enter the cell wall and break the lignin barrier [40]. During solid-state fermentation, fungal strains with detectable LiP activity show an increase in saccharification [56], which is enhanced with additional nutrients [45]. In fact, white rot fungi initially penetrate the lignocellulosic cell wall from the lumen to the secondary cell wall, followed by the middle lamella and cell corner $[57,58]$. In the fungal lignin degradation system, the theory of abiotic reaction on lignin degradation by lower molecular weight reagents, such as $\mathrm{Fe}^{3+}, \mathrm{OH}^{*}, \mathrm{Mn}^{3+}$, and $\mathrm{H}_{2} \mathrm{O}_{2}$, has recently resolved the puzzle of diffusion enzymes in the cell wall $[59,60]$. Upregulation of cellobiose dehydrogenases $(\mathrm{CDH}), \mathrm{LiP}$, and $\mathrm{MnP}$ has been detected when $P$. chrysosporium is grown on a mixture of cellulose and lignin [29] and various types of lignocellulosic biomass [28]. CDH forms a hypha/cellulose complex [61] that acts on cellobiose and converts it into cellobionolactone by either the electron sink model or the electron chain model [60]. During this process, $\mathrm{Fe}^{3+}$ is reduced to $\mathrm{Fe}^{2+}$ that spontaneously involves the Fenton reaction to produce free $\mathrm{OH}^{*}$ radicals in the presence of $\mathrm{H}_{2} \mathrm{O}_{2}$, and further manipulate demethoxylation and hydroxylation of lignin [62] as an intermediary for $\mathrm{Mn}^{3+}$ attack [22]. The diffusion of these small free radicals can occur predominantly in the secondary cell wall, which mainly contains structural carbohydrates and the aromatic backbone. Radicalization within the secondary cell wall contributes to structural swelling by breaking highly reactive linkages (related to hydroxycinnamates and $\mathrm{S}$ units). This creates easy access for higher molecular weight enzymes. The scheme of the $P$. chrysosporium degradation pattern on the cell wall is shown in Figure 6. It is assumed that the biodegraded lignin relatively lacks specific phenolic units, thereby enhancing enzymatic hydrolysis. However, further research is needed on these processes.

\section{Conclusion}

Biomass processing technologies and genetic engineering of plants can mitigate challenges in biomass conversion. Biodegradation of wheat straw by $P$. chrysosporium in terms of cellulose hydrolysis may not require complete depolymerization or deconstruction of the lignin complex. Rather, it may require dismantling specific substructures, including $S$ units, hydroxycinnamates, $\gamma$-ending structures, and $\mathrm{B}$ and $\mathrm{F}$ units. Therefore, this study provides important clues for enhancing saccharification of lignocellulosic biomass and guiding genetic modification targets in lignin biosynthesis. This study also offers a new insight into the challenges in removing lignin from biomass during pretreatment and reducing its effects on saccharification and downstream processes. The results reveal that targeting lignin in the secondary cell wall promises to provide a sustainable and effective approach for biomass saccharification.

\section{Methods}

\section{Preparation of $P$. chrysosporium and pretreatment}

P. chrysosporium ATCC 24725 was maintained in potato dextrose agar (PDA). Cultivation occurred at $28^{\circ} \mathrm{C}$ in 250-mL flasks for the spores' growth. After seven days of cultivation, fresh spores were suspended in $100 \mathrm{~mL}$ of sterilized water and subjected to count cell concentration with a Fisher Scientific hemacytometer. Wheat straw (Triticum sativum) grown in Moscow, Idaho was kept at $50^{\circ} \mathrm{C}$ until no weight loss was observed. One hundred grams of heat-dried wheat straw was soaked in $4 \mathrm{~L}$ of distilled water, autoclaved at $121^{\circ} \mathrm{C}$ for $20 \mathrm{mi}-$ nutes, and then the rest of the water was removed. After the wheat straw was cooled to room temperature, a 300$\mathrm{mL}$ spore solution with $10^{7} \mathrm{cell} / \mathrm{mL}$ was inoculated at the surface, and then manually rotated for 10 minutes. Incubations were performed at $37^{\circ} \mathrm{C}$ for two, four, six, and eight weeks. Sterilized wheat straw samples (100 g) were treated in plastic containers inside a low temperature 815 incubator (Precision Scientific) (see Figure 1A). The containers were covered with eight-layer gauze pads in 


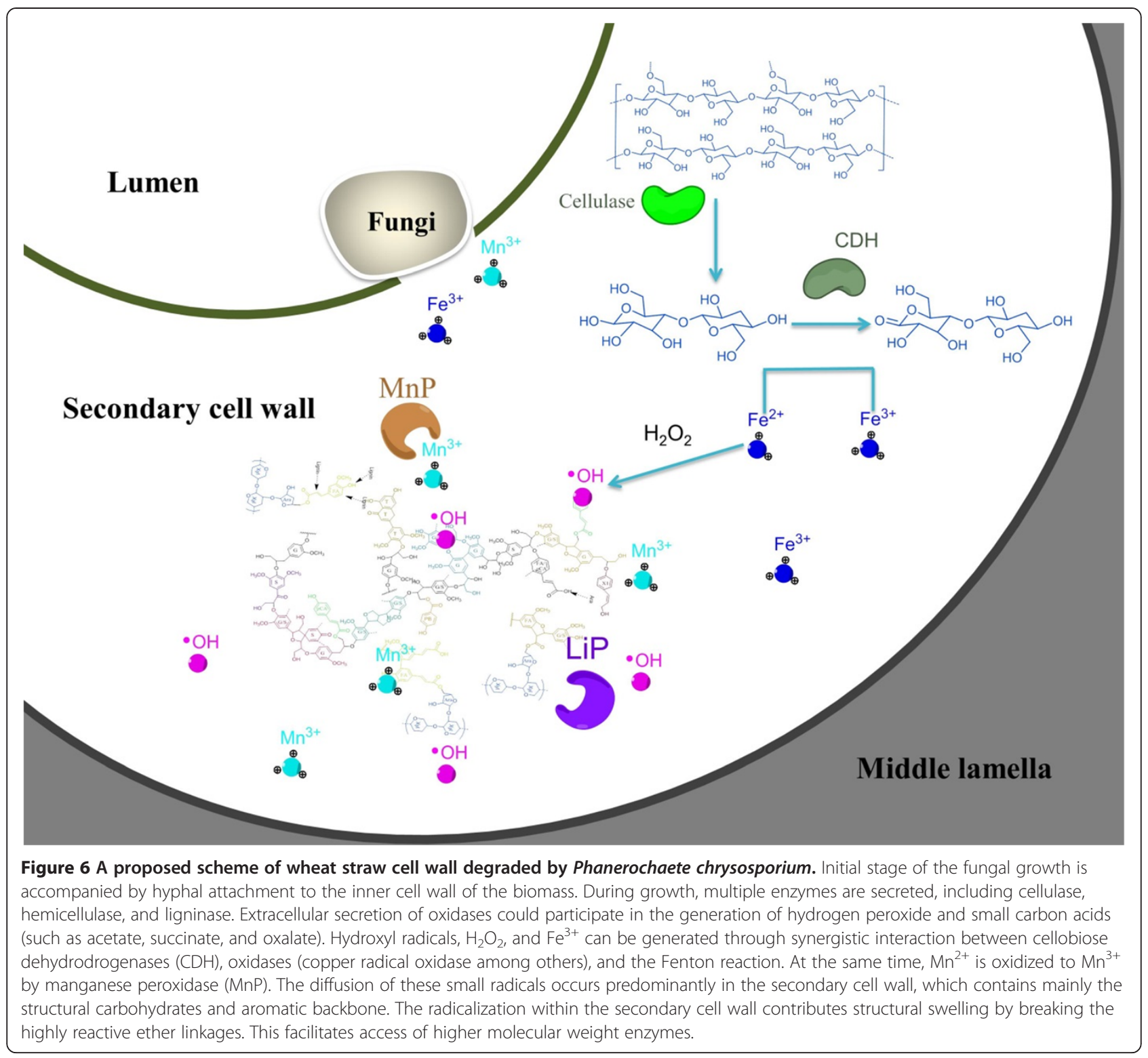

order to allow air exchange. Every 48 to 72 hours, $50 \mathrm{~mL}$ of water was evenly sprayed on the surface of the wheat straw while manually rotating the samples. At the end of the incubation periods, the samples were sequentially washed with water, dried, weighed, and chopped to size $0.25 \mathrm{~mm}$ ( $<60 \mathrm{mesh})$ before ball milling. The samples were then ball milled for 4 hours to a fine powder in a Retsch planetary ball mill, PM 100, with a zirconium dioxide ball at $300 \mathrm{rpm}$. The vessel rotated clockwise and anticlockwise every 3 minutes, with a 1 -minute interval break. The experiments were performed in triplicate.

\section{Enzymatic hydrolysis}

Enzymatic hydrolysis of the treated wheat straw was performed at $2 \%$ solids loading at $50^{\circ} \mathrm{C}$ for 48 hours under a cellulolytic hydrolysis solution. The cellulolytic solution was prepared by mixing 30 filter paper units (FPU)/g biomass cellulase from Trichoderma reesei ATCC 26921 (Sigma), 60 cellubiose units (CBU)/g biomass $\beta$-glucosidase Novozym 188 (Sigma), and 0.3\% w/w hemicellulase from Aspergillus niger in a $50 \mathrm{mM}$ sodium citrate buffer (pH 5.0). The sugar from the enzymatic hydrolysis was quantified with ion chromatography using an ion exchange chromatography apparatus (Dionex ICS-3000 DC IC) equipped with an electrochemical detector. All samples were separated using a Dionex Pac PA20 $(3 \mathrm{~mm} \times 150 \mathrm{~mm})$ with a CarboPac PA20 Guard $(3 \mathrm{~mm} \times 30 \mathrm{~mm})$. The flow rate was $0.5 \mathrm{~mL} / \mathrm{min}$, and the column temperature was maintained at $30^{\circ} \mathrm{C}$. The samples were eluted isocratically with $20 \% 52 \mathrm{mM} \mathrm{NaOH}$ and $80 \%$ water. The column was 
flushed between samples with 100\% $20 \mathrm{mM} \mathrm{NaOH}$, followed by deionized water. The sugar yield was calculated by comparing released sugars to total sugar in the biomass. The experiments were performed in triplicate.

\section{Chemical composition analysis}

Wheat straw samples were ground with a Wiley mill to pass through a 60 mesh screen and Soxhlet extracted with toluene:ethanol $(2: 1)$. The extractive free materials were further characterized by the two-stage acid hydrolysis method described by Standard Biomass Analytical Procedures (NREL) to determine the lignin and carbohydrate content [63]. The experiments were performed in triplicate.

\section{Solid-state ${ }^{13} \mathrm{C}$ NMR analysis}

Finely ground samples were packed in a $5.0 \mathrm{~mm}$ rotor with $1 \% \mathrm{w} / \mathrm{w} 3$-(trimethylsilyl) propionic-2,2,3,4- $d_{4}$ acid (TSP), and ${ }^{13} \mathrm{C}$ CP-MAS NMR spectra were recorded at an ambient temperature in a Bruker DMX 400 spectrometer (NMR center, Washington State University). The approximate composition analysis (lignin and carbohydrate contents) followed Gilardi's method (1995) [64]. The crystallinity of the biomass was estimated by dividing the area of the C4 crystalline peak (93 to $88 \mathrm{ppm}$ ) by the total area of the C4 peak (93 the $82 \mathrm{ppm}$ ) [65]. The experiments were performed in duplicate.

\section{Quantitative NMR analysis}

Milled straw lignin (MSL) and cellulase enzyme lignin (CEL) were extracted from untreated and biological degraded wheat straw, respectively. Details on the isolation and quantitation procedure are described in our previous work [36]. The well-ground samples were extracted with ethanol:toluene (1:2) for 12 hours, followed by repeated washing with ethanol and water to remove extractives. The crude MSL was then isolated by dioxane/ water $(96: 4, \mathrm{v} / \mathrm{v})$ and yielded by evaporation of the solvent. After dissolving in acetic acid/water (9:1, v/v), the MSL was precipitated in excessive water, freeze dried, redissolved in dichloroethane/ethanol $(2: 1, \mathrm{v} / \mathrm{v})$, and precipitated in ether again. The MSL removed residue was then subjected to enzymatic hydrolysis at $2 \%$ solids loading with $60 \mathrm{FPU} / \mathrm{g}$ cellulase and $120 \mathrm{CBU} / \mathrm{g}$ glucosidase in a $50 \mathrm{mM}$ sodium citrate buffer $(\mathrm{pH} 5.0)$ at $50^{\circ} \mathrm{C}$ for 72 hours. Crude CEL was consequently isolated in a dioxane/water solution $(96: 4, \mathrm{v} / \mathrm{v})$ and purified by the same purification procedure described above. The spectra of the isolated lignins were recorded in DMSO- $\mathrm{d}_{6}$ at $300 \mathrm{~K}$ on a Varian Inova $500 \mathrm{MHz}$ spectrometer (Agilent Technologies, Santa Clara, CA, USA) operating at 499.86 $\mathrm{MHz}$ for ${ }^{1} \mathrm{H}$ and $125.7 \mathrm{MHz}$ for ${ }^{13} \mathrm{C}$. The residual solvent signal at $2.49 \mathrm{ppm}$ for protons and $39.5 \mathrm{ppm}$ for carbon was used for internal referencing of chemical shifts. The value represented the number of specific units in 100 aromatic rings.

\section{Cellulase adsorption to MSL and CEL}

Cellulase adsorption to lignin was measured in a $15-\mathrm{mL}$ tube containing $2 \%(\mathrm{w} / \mathrm{v})$ lignin and $5 \mathrm{~mL}$ of $50 \mathrm{mM}$ citrate buffer $(\mathrm{pH} 4.8)$ with various cellulose loadings (25 to $100 \mathrm{mg} / \mathrm{g}$ lignin). The samples were incubated at $4{ }^{\circ} \mathrm{C}$ for 5 hours and were turned end-over-end manually every 10 minutes. After incubation, the tubes were centrifuged at $12,000 \mathrm{rpm}$ for 10 minutes. The cellulase concentration in the supernatant was measured using a BCA kit (Sigma). The experiments were performed in duplicate.

\section{Calculation of adsorption parameters}

The adsorption parameters (maximum adsorption capacity $\sigma$ and equilibrium constant $\mathrm{K}$ ) were calculated according to previously reported methods [7] using the Langmuir equation:

$$
[\mathrm{LE}]=\frac{\sigma[\mathrm{L}][\mathrm{Ef}]}{\mathrm{K}+[\mathrm{Ef}]} d
$$

where $[\mathrm{LE}]$ is the amount of adsorbed enzyme in $\mathrm{mg} / \mathrm{mL}$, [Ef] is the free enzyme concentration in $\mathrm{mg} / \mathrm{mL}, \sigma$ is the maximum adsorption capacity in $\mathrm{mg} / \mathrm{mg}$ lignin, [L] is the lignin concentration in $\mathrm{mg} / \mathrm{mL}$, and $\mathrm{K}$ is the equilibrium constant in $\mathrm{mg}$ of enzyme $/ \mathrm{mL}$. The affinity constant $(\mathrm{A}=1 / \mathrm{K})$ and binding strength $(\mathrm{S}=\mathrm{A} \times \sigma)$ were estimated.

\section{Additional files}

Additional file 1: Table S1. Chemical composition (\%) and weight (g) of wheat straw after biological degradation. Error bar represented as standard deviation

Additional file 2: Table S2. Klason lignin and carbohydrate content (\%) of isolated MSL and CEL. Error bar represented as standard deviation.

Additional file 3: Figure S1. The aromatic region of CEL isolated for two, four, six, and eight weeks treated and untreated wheat straw in HSQC spectra. H: p-hydroxyphenyl units; G: guaiacyl units; S: syringyl units; T: tricin units; $p C A$ : $p$-coumarate; FA: ferulate; PB: hydroxybenzoate.

Additional file 4: Figure S2. The aliphatic region of CEL isolated from two, four, six, and eight weeks treated and untreated wheat straw in HSQC spectra. A(a-OH): $\mathrm{a}-\mathrm{OH}$ in $\beta-\mathrm{O}-4$ linkage; $\mathrm{A}-\mathrm{H} / \mathrm{G}$ : coupled with $\mathrm{H}$ or $\mathrm{G}$ unit in $\beta-\mathrm{O}-4$ linkage; $\mathrm{A}-\mathrm{S}$ : coupled with $\mathrm{S}$ unit in $\beta-\mathrm{O}-4$ linkage; $\mathrm{A}(\gamma-\mathrm{Ac})$ : acylation by acetate in $\gamma-\mathrm{OH} ; \mathrm{A}(\gamma-\mathrm{pCA})$ : acylation by pCA in $\gamma-\mathrm{OH}$; $A \gamma$ : $\gamma-\mathrm{OH}$ in $\beta-\mathrm{O}-4$ linkage; $\mathrm{B}$ : phenylcoumaran ( $\beta-5)$; $C$ : pino/resinol $(\beta-\beta)$; D: dibenzodioxocins (5-5'/4-O- $\left.\beta^{\prime}\right)$; F: a, $\beta$-diaryl ethers; $X 1$ ( $\left.\gamma-\mathrm{OH}\right)$ : cinnamyl alcohol.

\section{Abbreviations}

Ay: $\gamma-\mathrm{OH}$ in $\beta-\mathrm{O}-4$ linkage; $\mathrm{A}(\gamma-\mathrm{Ac})$ : acylation by acetate in $\gamma-\mathrm{OH} ; \mathrm{A}(\mathrm{a}-\mathrm{OH})$ : $a-O H$ in $\beta-O-4$ linkage; $A(\gamma-p C A)$ : acylation by $p C A$ in $\gamma-O H ; A-H / G$ : coupled with $\mathrm{H}$ or $\mathrm{G}$ unit in $\beta-\mathrm{O}-4$ linkage; $\mathrm{A}-\mathrm{S}$ : coupled with $\mathrm{S}$ unit in $\beta-\mathrm{O}-4$ linkage; B: phenylcoumaran ( $\beta-5)$; $C$ : pino/resinol $(\beta-\beta)$; $C D H$ : cellobiose dehydrogenases; CEL: cellulase enzyme lignin; D: dibenzodioxocins (5-5'/4-O- $\left.\beta^{\prime}\right)$; E: Spirodienone $(\beta-1)$; F: $a, \beta$-diaryl ethers; FA: ferulate; G: guaiacyl units; $H$ : $p$-hydroxyphenyl units; 
MSL: milled straw lignin; PB: hydroxybenzoate; $p C A$ : $p$-coumarate; S: syringyl units; T: tricin units; X1: cinnamyl alcohol; X2: cinnamyl aldehyde.

\section{Competing interests}

The authors declare that they have no competing interests.

\section{Authors' contributions}

JZ participated in the conception, design, data collection and analysis, and drafted the manuscript. DG assisted in the laboratory work, results interpretation, and manuscript revision. DS and SC participated in critical discussions of the results and revised the manuscript. All authors read and approved the final manuscript.

\section{Acknowledgements}

The authors would like to acknowledge the Agriculture Research Center, Washington State University and the National Science Foundation (NSF Award Number 1231085) for financial support in this research. Many thanks to the Center for NMR Spectroscopy, Chemistry Department, Washington State University.

Received: 10 May 2014 Accepted: 16 October 2014

Published online: 29 November 2014

\section{References}

1. Chundawat SPS, Beckham GT, Himmel ME, Dale BE: Deconstruction of lignocellulosic biomass to fuels and chemicals. Annu Rev Chem Biomol Eng 2011, 2:121-145.

2. Bonawitz ND, Chapple C: The genetics of lignin biosynthesis: connecting genotype to phenotype. Annu Rev Genet 2010, 44:337-363.

3. Chundawat SPS, Donohoe BS, Da Costa SL, Elder T, Agarwal UP, Lu F, Ralph J, Himmel ME, Balan V, Dale BE: Multi-scale visualization and characterization of lignocellulosic plant cell wall deconstruction during thermochemical pretreatment. Energy Environ Sci 2011, 4:973-984.

4. Grabber JH, Ralph J, Lapierre C, Barrière Y: Genetic and molecular basis of grass cell-wall degradability. I. Lignin-cell wall matrix interactions. $C R$ Biol 2004, 327:455-465

5. Evtuguin DV, Amado FML: Application of electrospray ionization mass spectrometry to the elucidation of the primary structure of lignin. Macromol Biosci 2003, 3:339-343.

6. Kim H, Ralph J, Akiyama T: Solution-state $2 \mathrm{D}$ NMR of ball-milled plant cell wall gels in DMSO-d6. Bio Energy Res 2008, 1:56-66.

7. Kumar R, Wyman CE: Cellulase adsorption and relationship to features of corn stover solids produced by leading pretreatments. Biotechnol Bioeng 2009, 103:252-267.

8. Tu M, Pan X, Saddler JN: Adsorption of cellulase on cellulolytic enzyme lignin from lodgepole pine. J Agric Food Chem 2009, 57:7771-7778.

9. Ding S-Y, Liu Y-S, Zeng Y, Himmel ME, Baker JO, Bayer EA: How does plant cell wall nanoscale architecture correlate with enzymatic digestibility? Science 2012, 338:1055-1060

10. Studer MH, DeMartini JD, Davis MF, Sykes RW, Davison B, Keller M, Tuskan GA, Wyman CE: Lignin content in natural Populus variants affects sugar release. Proc Natl Acad Sci 2011, 108:6300-6305.

11. Rollin JA, Zhu Z, Sathitsuksanoh N, Zhang YHP: Increasing cellulose accessibility is more important than removing lignin: a comparison of cellulose solvent-based lignocellulose fractionation and soaking in aqueous ammonia. Biotechnol Bioeng 2011, 108:22-30.

12. Martinez D, Larrondo LF, Putnam N, Gelpke MDS, Huang K, Chapman J, Helfenbein KG, Ramaiya P, Detter JC, Larimer F: Genome sequence of the lignocellulose degrading fungus Phanerochaete chrysosporium strain RP 78. Nat Biotechnol 2004, 22:695-700.

13. Kirk TK, Higuchi T, Chang HM: Lignin biodegradation: microbiology, chemistry, and potential applications. Boca Raton, FL: CRC Press, Inc; 1980.

14. Hatakka A: Biodegradation of Lignin, Biopolymers. Vol. 1-Lignin, humic substances and coal. WeinHeim, Germany: Wiley-VCH; 2001.

15. Geib SM, Filley TR, Hatcher PG, Hoover K, Carlson JE, Del Mar J-GM, Nakagawa-Izumi A, Sleighter RL, Tien M: Lignin degradation in wood-feeding insects. Proc Natl Acad Sci 2008, 105:12932-12937.

16. Kirk TK, Farrell RL: Enzymatic " combustion": the microbial degradation of lignin. Annu Rev Microbiol 1987, 41:465-501.

17. Ten Have R, Teunissen PJM: Oxidative mechanisms involved in lignin degradation by white-rot fungi. Chem Rev 2001, 101:3397-3414.
18. Tien M, Kirk T: Lignin-degrading enzyme from the hymenomycete Phanerochaete chrysosporium Burds. Science 1983, 221:661.

19. Tien M, Kirk TK: Lignin-degrading enzyme from Phanerochaete chrysosporium: purification, characterization, and catalytic properties of a unique $\mathrm{H}_{2} \mathrm{O}_{2}$-requiring oxygenase. Proc Natl Acad Sci 1984, 81:2280-2284.

20. Hammel KE: Organopollutant degradation by ligninolytic fungi. Enzyme Microb Technol 1989, 11:776-777.

21. Martinez AT, Speranza M, Ruiz-Duenas FJ, Ferreira P, Camarero S, Guillen F, Martinez MJ, Gutierrez A, Del Rio JC: Biodegradation of lignocellulosics: microbial, chemical, and enzymatic aspects of the fungal attack of lignin. Int Microbiol 2005, 8:195-204.

22. Hildén L, Johansson G, Pettersson G, Li J, Ljungquist P, Henriksson G: Do the extracellular enzymes cellobiose dehydrogenase and manganese peroxidase form a pathway in lignin biodegradation? FEBS Lett 2000, 477:79-83.

23. Singh D, Zeng J, Laskar DD, Deobald L, Hiscox WC, Chen S: Investigation of wheat straw biodegradation by Phanerochaete chrysosporium. Biomass Bioenergy 2011, 35:1030-1040.

24. Chen S, Zhang X, Singh D, Yu H, Yang X: Biological pretreatment of lignocellulosics: potential, progress and challenges. Biofuels 2010, 1:177-199.

25. Zeng J, Singh D, Laskar D, Chen S: Deconstruction of native wheat straw lignin by Streptomyces viridosporus T7A. Int J Environ Sci Technol 2012, 10:165-174.

26. Renganathan V, Usha S, Lindenburg F: Cellobiose-oxidizing enzymes from the lignocellulose-degrading basidiomycete Phanerochaete chrysosporium: interaction with microcrystalline cellulose. App/ Microbiol Biotechnol 1990, 32:609-613.

27. Bao W, Renganathan V: Cellobiose oxidase of Phanerochaete chrysosporium enhances crystalline cellulose degradation by cellulases. FEBS Lett 1992, 302:77-80.

28. Adav SS, Ravindran A, Sze SK: Quantitative proteomic analysis of lignocellulolytic enzymes by Phanerochaete chrysosporium on different lignocellulosic biomass. J Proteomics 2011, 75:1493-1504.

29. Manavalan A, Adav SS, Sze SK: iTRAQ-based quantitative secretome analysis of Phanerochaete chrysosporium. J Proteomics 2011, 75:642-654.

30. Jeoh T, Ishizawa Cl, Davis MF, Himmel ME, Adney WS, Johnson DK: Cellulase digestibility of pretreated biomass is limited by cellulose accessibility. Biotechnol Bioeng 2007, 98:112-122.

31. Nakagame S, Chandra RP, Kadla JF, Saddler JN: The isolation, characterization and effect of lignin isolated from steam pretreated Douglas-fir on the enzymatic hydrolysis of cellulose. Bioresour Technol 2011, 102:4507-4517.

32. Nakagame S, Chandra RP, Kadla JF, Saddler JN: Enhanceing the enzymatic hydrolysis of lignocellulosic biomass by increasing the carboxylic acid content of the associated lignin. Biotechnol Bioeng 2010, 108:538-548.

33. Min D-y, Yang C, Chiang V, Jameel $\mathrm{H}$, Chang $\mathrm{H}$-m: The influence of lignin-carbohydrate complexes on the cellulase-mediated saccharification II: transgenic hybrid poplars (Populus nigra L. and Populus maximowiczii A.). Fuel 2014, 116:56-62

34. Palonen $\mathrm{H}$, Valtion Teknillinen $\mathrm{T}$ : Role of lignin in the enzymatic hydrolysis of lignocellulose. PhD thesis. Otameida Espoo: VTT Technical Research Centre of Finland; 2004.

35. Sewalt VJH, Glasser WG, Beauchemin KA: Lignin impact on fiber degradation. 3. Reversal of inhibition of enzymatic hydrolysis by chemical modification of lignin and by additives. J Agric Food Chem 1997, 45:1823-1828.

36. Notenboom V, Boraston AB, Kilburn DG, Rose DR: Crystal structures of the family 9 carbohydrate-binding module from Thermotoga maritima xylanase $10 \mathrm{~A}$ in native and ligand-bound forms. Biochemistry 2001, 40:6248-6256.

37. Zeng J, Helms GL, Gao X, Chen S: Quantification of wheat straw lignin structure by comprehensive NMR analysis. J Agric Food Chem 2013, 61.

38. Kim H, Ralph J: A gel-state 2D-NMR method for plant cell wall profiling and analysis: a model study with the amorphous cellulose and xylan from ball-milled cotton linters. RSC Advances 2014, 4:7549-7560.

39. Li H, Pu Y, Kumar R, Ragauskas AJ, Wyman CE: Investigation of lignin deposition on cellulose during hydrothermal pretreatment, its effect on cellulose hydrolysis, and underlying mechanisms. Biotechnol Bioeng 2014, 111:485-492.

40. Ragnar M, Lindgren CT, Nilvebrant NO: pKa-values of guaiacyl and syringyl phenols related to lignin. J Wood Chem Technol 2000, 20:277-305. 
41. Kishimoto T, Chiba W, Saito K, Fukushima K, Uraki Y, Ubukata M: Influence of syringyl to guaiacyl ratio on the structure of natural and synthetic lignins. J Agric Food Chem 2009, 58:895-901.

42. Zhou C, Li Q, Chiang VL, Lucia LA, Griffis DP: Chemical and spatial differentiation of syringyl and guaiacyl lignins in poplar wood via time-of-flight secondary ion mass spectrometry. Anal Chem 2011, 83:7020-7026

43. Yan L, Li W, Yang J, Zhu Q: Direct visualization of straw cell walls by AFM. Macromol Biosci 2004, 4:112-118.

44. Río Andrade JC, Rencoret Pazo J, Prinsen P, Martínez Ferrer AT, Ralph J, Gutiérrez Suarez A: Structural characterization of wheat straw lignin as revealed by analytical pyrolysis, $2 \mathrm{D}-\mathrm{NMR}$, and reductive cleavage methods. J Agric Food Chem 2012, 60:5922-5935.

45. Zeng J, Singh D, Chen S: Biological pretreatment of wheat straw by Phanerochaete chrysosporium supplemented with inorganic salts. Bioresour Technol 2011, 102:3206-3214.

46. Akin D, Sethuraman A, Morrison W, Martin S, Eriksson KEL: Microbial delignification with white rot fungi improves forage digestibility. Appl Environ Microbiol 1993, 59:4274-4282

47. Scalbert A, Monties B, Lallemand J-Y, Guittet E, Rolando C: Ether linkage between phenolic acids and lignin fractions from wheat straw. Phytochemistry 1985, 24:1359-1362.

48. Ralph J, Grabber JH, Hatfield RD: Lignin-ferulate cross-links in grasses: active incorporation of ferulate polysaccharide esters into ryegrass lignins. Carbohydr Res 1995, 275:167-178.

49. Lam T, Kadoya K, liyama K: Bonding of hydroxycinnamic acids to lignin ferulic and $p$-coumaric acids are predominantly linked at the benzyl position of lignin, not the $\beta$-position, in grass cell walls. Phytochemistry 2001, 57:987-992.

50. Hatakka A: Lignin-modifying enzymes from selected white-rot fungi: production and role in lignin degradation. FEMS Microbiol Rev 1994, 13:125-135.

51. Cantarella M, Mucciante C, Cantarella L: Inactivating effects of lignin-derived compounds released during lignocellulosic biomass pretreatment on the endo-glucanase catalyzed hydrolysis of carboxymethylcellulose: a study in continuous stirred ultrafiltration-membrane reactor. Bioresour Technol 2014, 156:48-56.

52. Bunzel M, Allerdings $\mathrm{E}$, Ralph J, Steinhart $\mathrm{H}$ : Cross-linking of arabinoxylans via 8-8-coupled diferulates as demonstrated by isolation and identification of diarabinosyl 8-8 (cyclic)-dehydrodiferulate from maize bran. J Cereal Sci 2008, 47:29-40.

53. Grabber JH, Hatfield RD, Ralph J, Zon J, Amrhein N: Ferulate cross-linking in cell walls isolated from maize cell suspensions. Phytochemistry 1995, 40:1077-1082

54. Grabber JH, Hatfield RD, Lu F, Ralph J: Coniferyl ferulate incorporation into lignin enhances the alkaline delignification and enzymatic degradation of cell walls. Biomacromolecules 2008, 9:2510-2516.

55. Grabber JH, Mertens DR, Kim H, Funk C, Lu F, Ralph J: Cell wall fermentation kinetics are impacted more by lignin content and ferulate cross-linking than by lignin composition. J Sci Food Agric 2009, 89:122-129.

56. Pinto PA, Dias AA, Fraga I, Marques G, Rodrigues MAM, Colaço J, Sampaio A, Bezerra RMF: Influence of ligninolytic enzymes on straw saccharification during fungal pretreatment. Bioresour Technol 2012, 111:261-267.

57. Blanchette R, Otjen L, Carlson M: Lignin distribution in cell walls of birch wood decayed by white rot basidiomycetes. Phytopathology 1987 77:684-690

58. Blanchette RA, Krueger EW, Haight JE, Akhtar M, Akin DE: Cell wall alterations in loblolly pine wood decayed by the white-rot fungus Ceriporiopsis subvermispora. J Biotechnol 1997, 53:203-213.

59. Arantes V, Milagres AMF, Filley TR, Goodell B: Lignocellulosic polysaccharides and lignin degradation by wood decay fungi: the relevance of nonenzymatic Fenton-based reactions. J Ind Microbiol Biotechnol 2011, 38:541-555.

60. Henriksson G, Johansson G, Pettersson G: A critical review of cellobiose dehydrogenases. J Biotechnol 2000, 78:93-113.

61. Igarashi K, Samejima M, Saburi Y, Habu N, Eriksson KEL: Localization of cellobiose dehydrogenase in cellulose-grown cultures of Phanerochaete chrysosporium. Fungal Genet Biol 1997, 21:214-222.

62. Henriksson G, Ander P, Pettersson B, Pettersson G: Cellobiose dehydrogenase (cellobiose oxidase) from Phanerochaete chrysosporium as a wood-degrading enzyme. Studies on cellulose, xylan and synthetic lignin. Appl Microbiol Biotechnol 1995, 42:790-796.

63. Sluiter A, Hames B, Ruiz R, Scarlata C, Sluiter J, Templeton D, Crocker D: Determination of structural carbohydrates and lignin in biomass. Lab Anal Proced 2008.

64. Gilardi G, Abis L, Cass AEG: Carbon-13 CP/MAS solid-state NMR and FT-IR spectroscopy of wood cell wall biodegradation. Enzyme Microb Technol 1995, 17:268-275.

65. Park S, Baker JO, Himmel ME, Parilla PA, Johnson DK: Cellulose crystallinity index: measurement techniques and their impact on interpreting cellulase performance. Biotechnol Biofuels 2010, 3:1-10.

doi:10.1186/s13068-014-0161-3

Cite this article as: Zeng et al:: Effects of lignin modification on wheat straw cell wall deconstruction by Phanerochaete chrysosporium.

Biotechnology for Biofuels 2014 7:161

\section{Submit your next manuscript to BioMed Central and take full advantage of:}

- Convenient online submission

- Thorough peer review

- No space constraints or color figure charges

- Immediate publication on acceptance

- Inclusion in PubMed, CAS, Scopus and Google Scholar

- Research which is freely available for redistribution 